\title{
Michael Carolan (2017), No One Eats Alone: Food as a Social Enterprise, Washington, Island Press ${ }^{1}$
}

\author{
Recensão de Sofia de Melo Araújo \\ Universidade do Porto (CETAPS/CITCEM/IF/ILCML) \\ IPP-Escola Superior de Educação
}

Pensar a alimentação - enquanto domínio social e civilizacional - é pensar todo o quadro de relações entre humanos, entre seres vivos, com o mundo natural e com conceitos ideológicos e filosóficos que nela se enquadram. Lyman Tower Sargent num texto publicado precisamente num volume co-editado por Michael Carolan, centrava a panóplia de dimensões de análise - estruturas de família e de comunidade, questões de género, dualidade urbano/rural, economia, saúde, política, - numa pequena teia de questões simples em torno dos "Como" e "Quem" da produção, distribuição e consumo alimentares (cf. Sargent, 2015). Também Michael Carolan encontra nos Food Studies um terreno propício e profícuo para uma análise sociológica ampla e poliédrica. Como o próprio dirá em No One Eats Alone: "food is not only a what, but also a when, a why, a how, and a with whom" (Carolan 2007a: 7).

Ao longo do seu percurso académico, o sociólogo Michael Carolan vive o estudo das questões alimentares como um laboratório privilegiado para a sua análise sociológica do modelo económico-político que ele decifra no mundo contemporâneo. Para isso reúne uma série de ângulos, abordagens e teorias. Nas palavras do autor, leva a cabo 
an approach embodied by assemblage thinking, vibrant materialism, geographies of care, enactive politics, and other styles of scholarship that look to describe how materialities, practices, and discourses matter in terms of their effects and affectivities. (Carolan 2017b: 136)

"Effects and affectivities", de facto, porque é de uma sociologia cultural, atenta às dimensões psicológica e histórica da experiência humana com a comida de que sempre falará Carolan. Por isso considera tanto os fenómenos como as interdições (legais ou culturais) de consumo e seus impactos ou o food shaming (cf. Carolan 2017a: 25). Por isso revela, afinal, marcas de fortíssima tolerância e amplitude na leitura do real, sem maniqueísmos e simplificações abusivas e doutrinárias. É um dos pontos mais notáveis de Carolan precisamente esta capacidade de reconhecer com uma certa bonomia e mesmo transigência a complexidade do mundo e da vida humana sem por isso prescindir de um papel interventivo e de uma reivindicação programática. Poderíamos dizer que há em Michael Carolan e na sua trajetória individual uma espécie de "one-man scholar activism", adaptando o termo tão em voga que dá mote ao encontro promovido pela British Library em Junho passado ("Scholar-Activism in the Twenty-First Century", 22 e 23 e Junho de 2018). É que, se a Biblioteca Britânica sugere aos oradores atenção a movimentos como "Black Lives Matter", "Decolonizing Education" ou "\#MeToo", o que encontramos em Michael Carolan é uma delineação própria de uma leitura do real, associada a uma resposta politizada, no mais nobre sentido do termo. Por isso é tão polifacetado nas análises e recusa as respostas colectivas que reduzem a complexidade dos fenómenos - veja-se a sua leitura crítica da chamada "Green Revolution", explanada em No One Eats Alone. Food as a Social Enterprise (Carolan 2017a: 10-14).

Assim, Carolan escolherá como objetivo do seu estudo - agora retornando aos Food Studies - o conceito de "foodscape", enquanto exemplificativo terminológico do seu próprio processo intelectual:

I opt for the term foodscape instead of the more familiar food system because the latter is too narrow for what I have in mind, often reducing the life of food to a commodity chain - producers, processors, distributors, retailers, and consumers. The hows and whys of food are more complex than that, involving questions of power, culture, relationships, feelings, citizenship, and more. (idem: 2 ) 
Por isso mesmo, como nos diz mais tarde no próprio No One Eats Alone, Carolan centra-se nas teias de relações económicas e sociais que explicam a aplicação que faz ao mundo da alimentação da sua teoria socio-economica "Cheaponomics":

networks that not only influence what's available and at what price but also how foods are perceived and by whom, and the relationships that make foodscapes desirable and doable, in terms of making sure they make available time, skills, and so forth. (idem: 117)

É por esta consciência de complexidade e de temporalidade das perceções alimentares que Carolan, em outros momentos da sua carreira, elegeu os textos utópicos como espaço desta reflexão. A comunidade explica e simultaneamente só a comunidade muda. Afinal, Carolan é claro: "That has been my point all along. The only way to change long-term behaviour is to build community". E esta atenção ao mundo das utopias não se esgota na edição do volume Food Utopias de 2015: há apenas alguns meses acaba de publicar um artigo intitulado "Justice Across Real and Imagined Food Worlds: Rural Corn Growers, Urban Agriculture Activists, and the Political Ontologies they live by", na revista científica Rural Sociology (Carolan 2018a).

Importa a cada momento recordar a viagem intelectual que Carolan faz e que pode ser sistematizada em três obras: The Real Cost of Cheap Food (2011), em que integra uma leitura económica e política dos fenómenos que vinha a estudar pela sociologia da agricultura; em 2014, com Cheaponomics: The High Cost of Low Prices, faz a ampliação macro do modelo concebido em micro; e agora, três anos mais tarde, revisita a teoria reaplicando-a ao terreno de testes original em No One Eats Alone.

Em toda a sua obra usa como marca essencial do seu tom típico a acessibilidade sem superficialidade ou facilitismo: Carolan observa em máxima complexidade e veicula na maior simplicidade possível. É por isso que num livro com todo o peso de exatidão e aprofundamento de um estudo científico, as metáforas são simples e dirigidas a um público amplo, como quando fala da experiência de gosto pelos consumidores perante hambúrgueres embrulhados ou não em papel de MacDonalds (cf. Carolan 2017a) e o humor não é considerado inapropriado: por exemplo, para falar da relação entre critérios estéticos 
e desperdício alimentar, sintetiza: "Bananas are vetted as if for a Hollywood casting call” (idem: 36). Ora, é essa clareza que permite ler os seus textos como um manifesto fundamentado, assente no objetivo continuado de apostar nos consumidores informados e ativos. Assegurando o acesso, Carolan permite-se exigir resposta: "If we think confort food comes in a package, and never think about how it got there, industry increases its bottom line and our collective well-being suffers" (idem: 3). Para Carolan, as regras perversas da Cheaponomics assentam precisamente na paralisação do consumidor interventivo - algo que retrata nas mais simples das circunstâncias: "The Marketplace makes exit easy, but at the expense of voice. Ever try complaining about a product or service?" (Carolan, 2017a: 149). Michael Carolan enfatiza a sua crença de que o conhecimento aumenta o ímpeto à ação, porque responsabiliza:

I would like to think that eaters are generally averse to human suffering. And yet, can you name an advertising campaign that zeroes in on hunger in Africa or pesticide poisoning in California when selling food? I can't, and I am sure I won't anytime in the foreseeable future. (idem: 47)

Como tal, Carolan coloca a exigência na veiculação extensa e articulada de informação e depois não teme tomar partido - teme apenas a falta de sustentação das afirmações e das práticas, assegurando, por isso, o papel interventivo do conhecimento. Por isso também se alia a iniciativas como a SACOM - Students and Scholars Against Corporate Misbehavior. Os seus livros - e o seu percurso académico - são científicos e políticos - uma coisa gera a outra, porque para Carolan o reconhecimento dos padrões da realidade atual só pode impelir à ação. E essa preocupação continua: em Março de 2018, como parte deste esforço continuado de consciencialização e activação dos consumidores, publicou "Big Data and Food Retail: Nudging out citizens by creating dependent consumers" (cf. Carolan 2018c). 0 esforço implica igualmente a denúncia dos artifícios da indústria, como quando o autor explica como a escolha entre artigos processados criados pelas mesmas multinacionais não é uma escolha real, e por isso insta à resposta: “Eaters' real power lies in their role as citizens, working together. That is the only way we can counter the weight of history - with a weight of our own, a collective mass" (Carolan 2017a: 143). 
The Real Cost of Cheap Food, publicado em 2011 e reeditado em 2018, avançou a teoria criada por Carolan - a que dará depois o nome de Cheaponomics - de que vivemos uma perversão das teorias socialistas numa subversão diretamente dirigida aos consumidores e assente na socialização dos custos, ditos externalizados:

This book, I hope, will cause them to re-evaluate their mental ledger that tells them that cheap is synonymous with inexpensive. It most certainly is not. The dominant food system socializes many of its costs, while simultaneously privatizing the majority of its benefits. This is not only egregiously unjust but makes for bad policy when the goal is affordable food. (Carolan 2011b: 5)

A reedição de 2018 adoptou um tom ainda mais marcadamente politizado: "It perpetuates a variant of socialism, actually cost socialism" [acréscimo]; "[...] the goal is to make foodscapes that afford people, households, and entire countries the ability to prosper" [alteração]. A oposição do sistema aos três Ps da sustentabilidade (People, Planet, Profit) é claramente denunciada (cf. Carolan, 2017a: 126). É notório que Carolan tem em mente um público ocidental e maioritariamente norte-americano e poderemos inferir que por isso usa a temida palavra "socialismo" como substituto do eufemismo "externalidade" para falar da socialização de custos, ou evita a discussão sobre optar por mais ou menos governo: "In the end, it is a matter of kind rather than of degree" (idem: 59). E, no entanto, não se abstém de oferecer uma contra-resposta num sentido afinal bem mais europeu:

It's time for policy that nudges food in a different direction. I am not suggesting that alternative foodscapes do unto Big Food as Big Food has done unto them - that is, push for legislation that explicitly makes it hard for conventional producers to operate. But we cannot level the playing field simply by making food-safety laws scale-neutral and focusing on outcomes (e.g., everyone keep food below 40 degrees Fahrenheit in order to retard bacterial growth) rather than processes (e.g., everyone use mechanized refrigeration). (idem: 56)

Para Michael Carolan, a sua missão central como intelectual é comprovar, exemplificar, intuir as roldanas do funcionamento do mundo para depois promover a mudança. Nesse esforço recorre a todo o tipo de abordagens científicas, destacando-se no 
caso dos Food Studies o embodied knowledge (em 2011 publica mesmo Embodied Food Politics): "If reformers hope to mount a serious challenge to the status quo, they will need to appreciate those aspects of food that are felt, practiced, and performed" (Carolan 2017a: 14). A teoria do embodied knowledge é usada, não numa torre de marfim fechada a académicos, mas como reconhecimento de uma resposta à realidade concreta da experiência criada pelo conhecimento histórico e sociológico, como quando o autor refere o exemplo da relação entre a Coca-Cola e a Primeira Guerra Mundial:

the embodied and therefore societal - as bodies do not exist in social vacuums - nature of taste goes even further than this. Sensory scientists might not always be tuned in to this reality. Food companies, however, most certainly are. (idem: 22)

Esta clara e consciente inserção na realidade concreta é uma marca fundamental da obra de Carolan, que simultaneamente assinala as pequenas questões de opções e confrontos culturais, das matrizes éticas impostas aos comportamentos, sem deixar que o entendimento anule a compreensão, ou o intelecto anule a empatia: "there's just something profoundly moving" (idem: 73), diz a propósito de partilhas de receitas entre grupos étnicos. 0 corpo não é obstáculo ao pensamento, é parte da discussão: "Notice how, even in our language about ethics, the body manages to sneak its way into the conservation" (idem: 54). Carolan já explicara bem as coordenadas do seu pensamento no referido Embodied Food Politics (2011):

I have long been fascinated by the subjects of knowledge, cognition, and perception, particularly from the angle of embodiment. What I have learned, and my own research has only strengthened my convictions, is that understandings of the world are inextricably shaped by lived experience. There is no mind, no mind's eye or disembodied reason, at least as those "things" are traditionally conceived in the Anglo-American analytic tradition that places a premium on a free and autonomous rational faculty. Rather, what we call mind, thought, cognition, and knowledge are all effects of active bodies, of bodies-in-the-world. (Carolan 2011: 1)

E assim, o corpo integra a compreensão de fenómenos como o do uso das ditas 
"calorias baratas" como forma de manter uma força laboral ativa e mal-paga mantida por uma economia do falsamente barato e vítima do efeito de "consumer remorse" (cf. Carolan 2017a: 140).

0 conhecimento profundo que lhe permite abordar temas diversos como a fome, a obesidade, os pesticidas tóxicos, a resistência a antibióticos, a depauperação laboral contemporânea e as deprimidas economias rurais é não apenas vasto, mas multifacetado e complexo: por isso discute a forma como comummente o conceito de "saudável" é equacionado como relativo meramente aos ingredientes (cf. idem: 76-80) e como isso se pode traduzir na comodificação da saúde (cf. idem: 81), ou como (e porquê) a obesidade se alia à pobreza (cf. idem: 127). Um exemplo da forma como Michael Carolan alia sociologia, economia e história, é a sua análise da exploração da criação de figuras ficcionais pelas empresas como forma de recuperar a ideia de saber experiencial numa era industrializada, com as narrativas a funcionarem como formas de resgatar a ideia de proximidade no consumo:

To fill in the knowledge gaps brought on by an increasingly industrialized foodscape, corporations offered consumers a steady diet of labels and advertisements - again, knowledge seeking to explain and even instruct [...]. Some early food manufacturers, for example, concocted a "founder" and a "founding story" to help assuage consumer concerns about eating food without a face, as when W. K. Kellogg began placing his signature on each package of Kellogg's Corn Flakes. (idem: 41)

E Carolan fá-lo com a sensatez de saber que o hoje não ultrapassou os perigos do passado e que não há absolutos nem maniqueísmos: "A century later, actors in alternative foodscapes are busy telling their own stories, but from the ground up" (idem: 43).

A sua reflexão inclui a dimensão humana e subjetiva da análise do real, não por leviandade de abordagem nem sequer por excessiva personalização do pensamento, mas sim com uma consciência académica e informada das dimensões de interpretação do mundo e da vida - note-se, por exemplo, a aproximação à "politics of recognition" de Charles Taylor (cf. idem: 64) ou as referências aos estudos sociológicos em torno de emoções e classes sociais por autores como Barbara Gray, Rodolfo Mendonza-Denton, 
Jennifer Kish-Gephart e Michelle Rheinschmidt. É isso que lhe permite, por exemplo, teorizar um "empathy gap” responsável pela menor consciência social das elites mais autónomas:

When talking to people who see themselves as part of the nebulous "alternative food movement," the subject of worker justice hardly comes up, not without my probing. Instead, I'm told repeatedly about the virtues of spatially compact foodscapes, of making food systems more local, with an eye toward reducing food miles. Often, though, social distance - living on different "sides of the tracks" so to speak - is a greater barrier than physical distance to people knowing, and thus empathizing with, each other. (idem: 62)

Como avança mais tarde, esta perceção é determinante no comportamento - uma ideia que reforça a sua crença na urgência e relevância de informar para gerar ação: "spatial and social distances help to normalize hurtful practices. As long as farm laborers remain invisible to wealthier consumers, employers will continue to treat them inhumanely" (idem: 66).

Há em Michael Carolan uma espécie de disponibilidade crítica que lhe permite suspender todas as assunções e respostas fechadas e assim abordar questões de grande complexidade como a dos avanços tecnológicos que permitem atingir objetivos que se tornam insustentáveis (note-se o caso da produção industrial de vitamina D refletida pelo químico reformado Yuk Wah: "We're trying to improve individual health at the expense of public health. Maybe ironic isn't the right word [...]. It's sad. Sad that that's what's going on and sad because we've gotten to a point where public health and individual health have come to mean different things" (apud idem: 80).

Michael Carolan está continuamente actualizado - conhece bem as peer-to peer networks Farmdrop, Open Food Network, The Food Assembly ou Farm Hack, por exemplo e é todo esse conhecimento profundo e inclusivo que lhe permite tomar opções radicalmente idiossincráticas - por exemplo, a referência a "civic dietetics" e o seu não enquadramento nas mesmas (cf. idem: 120). Ora, este reconhecimento e alinhamento permitem responder a um momento histórico que alguns vivem como de mudança eminente - um agricultor, Jack, diz a Carolan: "The more consumers understood our food, the less they'll feel comfortable with that crap at the store [...]. It's a food revolution, man!" (idem: 44) e ele próprio resume em relação aos entrevistados: "They all express a desire to 
create citizens rather than just consumers" (idem: 139). Na constante denúncia do real por exemplo, considera "processed" mero eufemismo para "energy subtracted" e "greenhouse gas emitted" (cf. idem: 80) - o autor analisa OGMs, fast food, e todo o tipo de questões, sempre alerta a todos os lados de cada questão:

There is a growing constituency of thoughtful, bright, and well-intentioned food scientists, public health professionals, and executives championing the health benefit of fast food. Seriously. This position made a particularly notable splash in 2013 when David Freedman published a piece in the Atlantic Monthly bombastically titled "How Junk Food Can End Obesity". The essay extols the benefits of fast and cheap processed foods for improving the health of eaters around the world. (idem: 75)

A abertura, no entanto, segue a par com um combate determinado ao "achismo", à falta de fundamentação. Note-se o caso do artigo de Andrew Odegaard e colegas que pareciam encontrar nos níveis de educação e de actividade física elevadas em Singapura um acréscimo em ataques cardíacos: Carolan partilha a denúncia de que o que está na raiz do problema é a mudança de dieta desse mesmo grupo (cf. idem: 91).

Toda a análise assenta naquilo que Michael Carolan avança no terceiro capítulo, "Shaping Values": a ideia de que, ao contrário da generalidade dos livros sobre comida, não foge às questões éticas (cf. idem: 45), e, simultaneamente, a relevância ética que dá ao conhecimento amplo de circunstâncias e elementos: "In any discussion of values, context matters immensely" (idem: 48). Como o próprio Carolan sintetiza: "Ethics, in a word, are made real through practice" (idem: 54).

Há, assumidamente, um ideal político e filosófico na escrita de Michael Carolan, e esse ideal chegou-nos já em 2011:

I, for one, think our food system should do more than just produce food cheaply, especially of its cheapness is a product of bad accounting, where most costs are externalized. Discussing what a food system ought to do - rather than busying ourselves with higher level debates like is slow or fast, small-scale or large-scale, local or global "better" - helps avoid the problematic traps that have sidelined the food debate in recent decades. (Carolan 2011a: 150) 
Esse ideal vem acompanhado de um forte apelo à ação, mas um apelo pejado de realismo:

Any revolution begins with people working together, sacrificing time and energy for a cause they believe in. But eventually, unless we want to base our future foodscapes on notions of sacrifice, we are going to need to make it convenient for people to participate in these more civic-minded foodscapes. (idem: 127)

Este tratado académico, apoiado numa bibliografia exaustiva, oferece um conhecimento profundo da história do pensamento na área e uma consciência da complexidade sem panaceias e New-Agisms. Note-se a forma crua como aborda o ideal das cooperativas:

The cooperativeness of cooperatives is often assumed in practice. After all, most people involved in such forms of social organizing likely consider themselves to be cooperative. However, as demonstrated in this paper, legal status alone does not guarantee cooperative relationships. Decisionmaking processes can be exclusive, leadership can disempower, and emotional work can limit the ability to work across socio-cultural difference. In this way, when we speak of cooperation, it is important to ask: cooperative for whom? (Hale/Carolan 2018)

Esta leitura desingénua da realidade que rejeita a política cómoda de que a informação simplificada basta, ao disfarçar em factual e objetiva a complexidade real (cf. Carolan, 2017a: 56-7), fá-lo alinhar com a tolerância de George Orwell nas críticas às bemintencionadas fabianas que, ao estilo de Jamie Oliver na atualidade, restringem a mudança de comportamentos a um ato de vontade:

When food writers - sorry Michael Pollan - are asked to give eaters advice and respond by saying "Just cook!" I cringe. Intellectually, it may sound like solid instruction. But that is also its problem; it is a recommendation abstracted from the realities of lived experience, especially among populations (read: women) that already struggle under the weight of time poverty. My interviews support existing research on the subject. (idem: 100) 
Em resumo, No One Eats Alone, como o restante da obra de Michael Carolan, é uma compilação de ideias, olhares e dados destinada, como um todo, a nutrir mudanças coletivas, reconhecendo de forma nítida e sóbria as dificuldades sem perder qualquer ânimo: "Just remember, though - all locks can be picked. Or kicked in" (idem: 144). Para esse poder, urge confrontar as opiniões pré-estabelecidas e rejeitar ilusões e respostas facilitistas:

There is an old saying in the social sciences: be careful what you are looking for because you will probably find it. The adage is a reminder to be reflective about the questions we ask and the assumptions we make in our quest to answer them. (idem: 110)

We have to be careful not to romanticize farmers as only understanding and being capable of understanding analog technologies. The yeomen farmers of yesteryear are just that, a nostalgic image with very little resemblance to the growers and ranchers I know. Some of those I interviewed acknowledged the value of circulating digital information among networks as another way of reducing farmer dependency on firms and "approved" service providers [...]. It doesn't have to be alienating if we develop it together: in other words, the specific technology we use is not as important as how that technology connects us. (idem: 136)

Por esse olhar crítico, o testemunho da informação é passado ao consumidor que o lê, ao leitor que consome. E para Carolan, o conhecimento responsabiliza:

It is time to rethink things"; "Radical change can occur only when people start acting like citizens first and consumers second. Otherwise we're left with "choice" that consists of Coke versus Pepsi. (idem: 5)

Agora, já sabe. 


\section{NOTA}

${ }^{1} \mathrm{O}$ presente trabalho foi realizado no âmbito do Projeto ALIMENTOPIA / Utopian Foodways, financiado por Fundos FEDER através do Programa Operacional Competitividade e Internacionalização - COMPETE 2020 e por Fundos Nacionais através da FCT - Fundação para a Ciência e a Tecnologia (PTDC/CPC-ELT/5676/2014 | POCI-01-0145-FEDER-016680).

\section{Bibliografia}

Carolan, Michael S. (2011a), Embodied Good Politics, Surrey, Ashgate.

-- (2011b), The Real Cost of Cheap Food, Oxon and New York, Routledge.

-- (2017a), No One Eats Alone. Food as a Social Enterprise, Washington, Island Press.

-- (2017b), "Publicing Food: Big Data, Precision Agriculture, and Co-Experimental Techniques of Addition", in Sociologia Ruralis - Journal of the European Society for Rural Sociology, volume 57, issue 2, April, 135-54.

-- (2018a), "Justice across Real and Imagined Food Worlds: Rural Corn Growers, Urban Agriculture Activists, and the Political Ontologies They Live By", in Rural Sociology, 15 February in https://onlinelibrary.wiley.com/doi/abs/10.1111/ruso.12211 (último acesso em 4/12/2018).

-- (2018b), "Justice Across Real and Imagined Food Worlds: Rural Corn Growers, Urban Agriculture Activists, and the Political Ontologies they live by", in Rural Sociology, 15 February 2018, 1-34, 10.1111/ruso.12211. 
-- (2018c), "Big Data and Food Retail: Nudging out citizens by creating dependent consumers", in Geoforum, volume 90, March, 142-50.

Hale, James / Michael Carolan (2018), "Cooperative or uncooperative cooperatives? Digging into the process of cooperation in food and agriculture cooperatives", in Journal of Agriculture, Food Systems, and Community Development, Advance Publication Online in http://doi.org/10.5304/jafscd.2018.081.011 (último acesso em 4/12/2018).

Sargent, Lyman Tower (2015), "Everyday Life in Utopia: Food", in Paul V. Stock, Michael Carolan e Christopher Rosin (ed.) (2015), Food Utopias. Re-imagining citizenship, ethics, and community, Oxon, Routledge, 14-32. 